HOW, a Colombian Journal of Teachers of English. No. 3, (pp. 61-67). (ISSN: 0120-5927). 1997.

APA citation style: Benavides B., Jorge E. (1997). CALL, within the Language Learning Methodology. HOW, a Colombian Journal of Teachers of English) (3), 61-67.

\title{
CALL within the Language Learning Methodology
}

\author{
Jorge E. Benavides B. (joelbebu@gmail.com) \\ Departamento de Lingüística e Idiomas \\ Universidad de Nariño, San Juan de Pasto, Colombia
}

\section{Overview}

The expansion of Educational Technology during the 70's, 80's and mid 90's has been very significant in education, yet there have been no challenges posed to it from fields like cognitive science and Information Technology.

It is said, as mentioned in Hawkridge, (1990) that there is a trend toward the adoption of new theories of learning like Piaget's constructivism and Vygotsky PZD (Proximal Zone Development) since Skinner's behaviorism cannot account for the complexity of human cognition even though it has greatly influenced Education Technology up to the present. Criticism from Educational technologists questions the persistence of educational technology with the behaviorist model, especially if the answer to whether the study of human behavior providing sufficient basis for understanding learning is in the affirmative. Piaget's and Vygotsky's approaches may provide new grounding for sketching a methodological basis for Education Technology.

There is not much to discuss about the changes produced by Information Technology in education, especially with the introduction and use of affordable microcomputers. Thus, with the information revolution and the arrival of Information Technology, mainly in the form of computers, there is a challenge posed for Educational Technology. This challenge could be expressed in terms of how and to what extent Educational Technology will accommodate to make Information Technology an exploitable resource in Education.

It would be interesting to see how Educational Technology with its resources could play an important role in helping provide the context for changes in language teaching and learning to happen. Also, Information Technology with the use of computers could also contribute to the aim of achieving progressively more autonomy in the field of language learning.

\section{Changes caused by the Information Revolution and Information Technology}

There are some changes caused by the technology on the way information is handled in a variety of human activities, especially in education. In the first place, the information revolution has 
HOW, a Colombian Journal of Teachers of English. No. 3, (pp. 61-67). (ISSN: 0120-5927). 1997.

meant that it must be available and accessible to everybody. Therefore, if we have information we have the starting point for the solution of problems, the completion of tasks, or the making of decisions. The new technological developments provide the means for storing it so that it can be easily and quickly accessed. For this reason this age of information is sometimes described as a post-industrial economy, where it can take the place of other forms of wealth such as capital.

In the second place, we have a situation in which a great deal of educational processes involves information and such mental processes as ordering it, presenting, processing, interpreting and looking for value in it. This is why the new forms of availability and accessibility through technological developments with computers have profound implications for these aspects of education, implications which are as yet unclear and about which there is bound to be controversy. We are not yet certain about important changes arising out of the new technology. They may result in new approaches to information, or perhaps, as many educators expect, from direct changes in pedagogy using computer assisted learning systems.

\section{A pseudo-methodological framework for CALL.}

CALL has undergone quite different stages since the introduction of computers in language teaching and progressively into language learning. Since its beginnings CALL has struggled to accommodate to the contextual situation, that is, to progressively match its technology with current methodological practices.

In its beginnings CALL was relegated to mechanical and routine aspects of language teaching. The drill and practice procedure was usual during the seventies and eighties. However, a more communicative approach to CALL was indeed sought.

Today CALL is involved in more communicative activities and the interaction user-computer, useruser is said to be far more advantageous in terms of production and more cognitively demanding. However, CALL has reached a stage in which people are trying to find a pedagogically sound scheme to account for the different processes which can be achieved by using a computer, computer-based materials and consequently by different learning scenarios. In other words, we need to start establishing a supportive pedagogy which does not necessarily encompass to current methodological theory. Often times CALL activities, software, the machine itself, not to mention the interaction achieved within a CALL environment have been questioned in terms of their pedagogical value. Nonetheless, there has been a lot of effort to introduce, and filter the new technology in educational contexts, with promising results and this is sometimes disregarded by most critics, or technophobic educationalists.

As Phillips (1985), and Weible (1987), (mentioned in Hubbard, 1992) put it, CALL and its technology has been striving and searching for an appropriate and effective methodology. 
HOW, a Colombian Journal of Teachers of English. No. 3, (pp. 61-67). (ISSN: 0120-5927). 1997.

Through its different stages, CALL has been being established as a stand- alone discipline, and abundant literature supports the need for a methodological framework for CALL. Consequently, several efforts have been made in order to achieve this goal. Higgins $(1983,1988)$, Underwood (1988), Phillips (1985), and Wyatt (1987), to mention just a few, and lately Hubbard, (1992) have come up with some ideas of how a methodological framework for CALL can be established in the domain of courseware and materials development.

Using the experience of the people engaged in the development of CALL, its effectiveness, advantages, disadvantages, limitations, capabilities through approximately two decades of its permanence in language teaching and language learning, it is possible to suggest a general view of CALL as a more identifiable type of "method" in language teaching and learning. This way we will be looking forward to making CALL not only revolutionary but also an evolutionary process.

We will be looking for a place among current language methodology as well as general learning theories, as perhaps Hubbard (1992), put it in one of his principles for suggesting a methodological framework:

"The framework should be based to the degree possible on existing frameworks or views of methodology for language teaching and learning in general. This makes it easier to interpret and aids in integrating CALL into, rather than isolating it from the language teaching profession at large." (Hubbard, 1992:42)

Hubbard considers that a CALL framework has to relate to existing frameworks with a general coverage of language teaching and learning. This model taken from Richards \& Rodgers (1982) in which there are three levels of organization: Approach, Design and Procedure will be used for relating CALL to existing methodologies, without implying that CALL is a true method, but for the sake of understanding some of the aspects of CALL that make it similar to or different from other methods. We will take a look at the two first aspects (Approach and Design), since the third is beyond the scope of this article.

\subsection{Approach}

\subsubsection{Theories of language learning}

This part deals primarily with the theories of learning in general related to educational software and the use of computers in language learning in a more specific domain. We will briefly take a look at three of the most important theories which most of second and foreign language teaching and learning contexts had to deal with.

The first theory applied Skinner's behaviorist theory to account for measurable behavior and positive and systematic reinforcement. Behaviorism does not account for language production 
HOW, a Colombian Journal of Teachers of English. No. 3, (pp. 61-67). (ISSN: 0120-5927). 1997.

which is quite different from discrete fixed responses. However, Skinners's theory is not completely rejected since there are some forms of learning which may be originated from the type of stimulus-response schemata (low level specific fact and motor skills), the type of drill-andpractice computer programs exhibited in the beginnings of CALL usually reflecting what at that time was known as Programmed Instruction (PI) and Programmed Learning (PL).

Since in this theory the learner is seen as a passive entity from which responses can only be elicited by external stimuli, then a more plausible theory of learning which views language learning as an active and constructive process has to be considered. Jean Piaget's view of learning as a process in which the learner is actively involved, reviewing experience, validating hypotheses and constructing from previous knowledge is translated by Seymour Papert (1980) into the Educational Computing area, by providing young learners with tools for constructing knowledge and understanding.

The constructivist approach (Piaget's learning theory) named because of its emphasis on the learner's construction of his own understanding inspired Papert to work out a model of how computers can be used in education, using the LOGO programming language in children which showed the possibilities of using educational software. The idea of children's thinking developing from sensor motor, concrete reasoning and abstract reasoning gives CALL the possibilities of working through different stages, according to the developmental stages of the individual.

The third theory of language learning which is also taken as a reference for CALL is Vygotsky's view of communicative learning. The first and second views of learning are oriented towards the learner as an individual and the view of individualized learning through the use of computers. With Vygotsky's view of learning CALL integrates a more humanistic and communicative aspect of it, since this learning process not only involves learners, but also teachers and the whole community. Social context is then introduced as an important component of learning in CALL.

In this third view, language learning is socially dependent, and therefore the role of the teachers is not dismissed since the learner will develop through language by learning to interact with others. CALL then, has to see the learner as an active communicative participant in learning where the computer and the software provide the context for learning and communicating with teachers and learners.

\subsection{Design}

In this part of the framework we will dedicate special attention to the roles of the teacher, the role of the learner and the role of the computer and try to relate them to the current views of learning in general and language learning in particular. 
HOW, a Colombian Journal of Teachers of English. No. 3, (pp. 61-67). (ISSN: 0120-5927). 1997.

\subsubsection{The role of the teacher.}

In the view of Mercer, (1993) taking the Vygotskyan theory of language learning and teaching, the teacher in CALL is seen as having a crucial role in supporting the learner. The teacher provides support in helping learners to convert their knowledge and understanding into a tool for gaining control of his or her situation, thereby progressively increasing learning strategies and building autonomous learning. The teacher is then a very specialized and skilled person who will know when he or she has to intervene or not, reducing his or her intervention to a minimum in order to progressively promote learner independence.

According to Mercer (1993), one of the attractions of the Vygotskyan point of view is the fact that he describes and explains not just learning but the process of teaching and learning. Fisher (1993), in accordance with Higgins, $(1984,1988)$ points out that the introduction of computers will contribute to a change in the teacher's attitudes toward managing learning, that is, the teacher will have a more facilitating and less controlling style of working in order for the learner to explore and allow some degree of freedom. In addition, since it would be impossible for the teacher to know in detail every program used for language learning and have answers for each of the activities, then, he becomes a co-learner, identifying himself with the learner and thereby approaching the position of the latter. This would give him the possibility of understanding the learning situation from the learner's point of view. Still another ingredient in this situation is that the teacher could become a less threatening source of input. This presumably will be taken advantage of for more effective learning, since the teacher is deprived of the status of the master of knowledge. The contribution of the computer can certainly be regarded here as playing that part of the teacher's role a provider of input for the students to test their hypotheses.

\subsubsection{The pedagogue/magister dichotomy}

Higgins $(1984,1988)$ views the teacher ideally as the instructor directing students unilaterally, while the pedagogue is like a slave following a step behind ready with a clue or answer when asked. The role of the teacher is diminished with respect to that of the student, in providing control over modalities for learning and in attempting to compensate for individual differences.

Computer-Assisted Language Learning seeks ways to empower individuals in order to direct their own learning, rather than ceding control over learning to an authoritative entity, as in behavioral models. Below we can find Higgins' view of the differences between Magister and Pedagogue.

The Magister:

-directs students' learning

-has authority to evaluate, praise, censure structure the order of events

-explains rules, gives examples

-repeats endlessly 
HOW, a Colombian Journal of Teachers of English. No. 3, (pp. 61-67). (ISSN: 0120-5927). 1997.

The Pedagogue:

-assists students' learning

-has no authority in censuring

-provides no structure

-answers students' questions

-follows students' suggestions

At this point, it is fair to clarify that Higgins is not against 'magisterial thinking' and he considers that teachers as part of the learning process are still very important; however, he stresses the fact that when this 'teaching-oriented process' predominates, learners may be discouraged from extending their learning through productive exploration and discovery.

\subsubsection{The role the teacher as part of a learning community}

According to Vygotsky, what is important in learning is not only 'solo performance' but a wider social transaction different from what has traditionally been emphasized in the search for the development of individual knowledge and intelligence. This contrasts with Piaget's view of the role of the teacher as a provider of 'rich learning environments'. However, what is especially interesting in Piaget's view of the role of the teacher is that of being considered as a facilitator in the learning process. Interestingly related to Piaget's view of learning is Higgins' consideration of the pedagogic role of the teacher in language learning as being the person (the pedagogue) who is always behind the learner, proving answers to his questions in what has been regarded as a leading from behind approach in the teacher's role. This is something completely different to the traditional overemphasized teacher-controlled approach where the teacher sets the pace, the content and the mode of every 'learning'.

As we can see, in this context the most appropriate role for the teacher could be the one that limits his intervention in the learner's process of learning, as the learner progresses in the continuum of autonomous learning. For example, it is seen from experience that often times students' performance is better (spontaneous, and natural) when the teacher is not present. The teacher as an organizer of the newly enriched learning environment has to approximate his educational goal of being an effective factor in the students' cognitive development, especially when working with young learners.

\section{As a conclusion}

Perhaps CALL cannot yet be considered a method in itself but it is evident that through its potential, physical validity and flexibility many of the features of classic and modern methodologies can be integrated. Are we close to an eclectic framework for language learning and 
HOW, a Colombian Journal of Teachers of English. No. 3, (pp. 61-67). (ISSN: 0120-5927). 1997.

teaching through CALL? This is also something to be considered and taken into consideration seriously, for the possibilities of hardware and software design and software applicability can be as varied as many of the methodological features of most methods and approaches.

\section{REFERENCES}

Fisher, E. (1993). The teacher's Role. In P. Crimshaw. (ed.) Language Classrooms and computers. London: Routledge.

Hawkridge, D. (1990). Challenging Educational Technology. Educational and training Technology International, 28, 2, 102-109.

Higgins, J (1983). Can computers teach? CALICO Journal, 1: 2, 4-6

Higgins, J (1988). Language, learners and Computers. London: Longman.

Hubbard, P. (1992). A Methodological Framework for CALL: Courseware Development. In M. Pennington, \& V. Stevens (eds.). Computers in Applied Linguistics. Clevedon: Multilingual Matters Ltd.

Mercer, N. (1993). Computer-based Activities in Classroom Context, in P. Crimshaw. (ed). Language Classrooms and computers. London: Routledge.

Papert, S. (1980). Mindstorms: Children, Computers, and powerful Ideas. New York: Basic Books.

Philips, M. (1985). Logical possibilities and classroom scenarios for the development of CALL. In C. Brumfit, M. Philips \& P. Skehan (eds.) Computers in English Language Teaching. New York: Pergamon.

Richards, J. \& T. Rodgers (1986). Approaches and Methods in Language Teaching. Cambridge: Cambridge University Press

Underwood, J. (1984). Linguistics, Computers and the Language Teacher: A Communicative Approach. Rowley, MA: Newbury House.

Underwood, J. (1988). Computer-based learning. London: David Fulton Publishers.

Weible, D. (1987). Towards a media-specific methodology for CALL. In W. Flint Smith (ed.), Modern Media in Foreign Language Education: Theory and Implementation. Lincolnwood, IL: National Textbook Company.

Wyatt, D. (1983). Three major approaches to developing computer-assisted language learning materials for microcomputers. CALICO Journal, 1: 2, 34-38. 